\title{
Analisis Karakteristik Traksi Serta Redesign Rasio Transmisi Jetbus 2 High Deck Adiputro
}

\author{
Muhammad Alawy Djufri dan I Nyoman Sutantra \\ Departemen Teknik Mesin, Fakultas Teknologi Industri, Institut Teknologi Sepuluh Nopember (ITS) \\ e-mail: tantra@me.its.ac.id
}

\begin{abstract}
Abstrak - Penjualan kendaraan bermotor Indonesia tahun 2017 mengalami peningkatan 5,96 persen dari tahun sebelumnya. (Gaikindo). Tingginya penjualan kendaraan tersebut tidak diiringi dengan upaya produsen untuk mencerdaskan konsumen mengenai performa kendaraan. Hal tersebut yang mendasari penulis untuk melakukan analisa karakteristik traksi pada Jetbus 2 High Deck Adiputro. Dalam penelitian ini menganalisa menggunakan dua Engine dengan volume ruang bakar yang sama (cc). Telah dilakukan tiga tahapan pengujian. Tahapan pertama adalah dilakukan analisa perhitungan kecepatan dan percepatan bus. Tahap kedua dilakukan analisa perhitungan sudut tanjak maksimum yang mapu dilalui oleh bus. Selanjutnya Tahap ketiga telah dilakukan redesign rasio transmisi bus adiputro menggunakan progressi geometri. Dari penelitian ini di dapatkan data berupa kecepatan, percepatan, dan sudut tanjakan pada kondisi standar dari 2 engine yang di analisa serta hasil redesign rasio transmisi bus adiputro dari 2 engine $\mathrm{J08} \mathrm{E}$ VD dan J08E UN . Setelah dilakukan analisa kedua engine tersebut gradeability maksimum yang mampu di tempuh tidak sesuai dengan klaim pabrikan sebesar $32.3 \%$. Sedangkan analisa kecepatan maksimum yang mampu di capai kendaraan adalah $116 \mathrm{Km} / \mathrm{jam}$ untuk engine J08E VD dan $117 \mathrm{Km} / \mathrm{jam}$ untuk engine J08E UN dengan klaim dari pabrikan $100 \mathrm{Km} / \mathrm{jam}$. Setelah dilakukan redesign gradeability maksimum yang mampu di capai meningkat $38 \%$ untuk engine J08E VD dan $39 \%$ untuk engine J08E UN.
\end{abstract}

Kata Kunci-Karakteristik Traksi, Redesign, Progressi Geometry, Gradeability.

\section{PENDAHULUAN}

$\mathrm{B}$ ERDASARKAN data Gabungan Industri Kendaraan Bermotor Indonesia (Gaikindo) menunjukkan penjualan mobil pada kuartal I 2017 tercatat sebanyak 283.245 unit, naik sebesar 5.96 persen dibandingkan capaian pada periode yang sama tahun lalu yakni 267.302 unit [1]. Membuktikan kebutuhan akan kendaraan di Indonesia sangat tinggi yang mayoritas digunakan untuk transportasi. Transportasi di Indonesia beragam mulai dari bus, kereta hingga kapal laut. Bus menjadi pilihan transportasi massal utama mulai dari antar kota hingga antar provinsi. Perusahaan Otobus di Indonesia semakin bertambah, hingga sekarang tercatat lebih dari 300 perusahaan otobus yang beroperasi. Banyaknya perusahaan otobus membuat armada bus juga semakin banyak. Namun pemilihan untuk menentukan bus yang tepat sesuai dengan kebutuhan kurang dimiliki oleh setiap pemilik perusahaan otobus.

Bus yang di miliki oleh perusahaan otobus merupakan hasil produksi perusahaan karoseri. Perusahaan karoseri bus dalam pameran maupun brosurnya hanya menampilkan pengetahuan umum tanpa menyertakan spesifikasi lengkap dari kendaraan. Pengetahuan spesifik dari segi transmisi memiliki peran penting untuk mengetahui kecepatan bus dan kemampuan bus untuk melewati tanjakan, sehingga kecelakaan bisa diminimalisir. Kemampuan kendaraan untuk melaju serta mengangkut suatu beban disebut kinerja traksi kendaraan. Pengetahuan kinerja traksi kendaraan yang kurang di ketahui oleh perusahaan otobus dalam pemilihan bus.

Perusahaan karoseri yang ada di Indonesia salah satunya adalah PT. Adiputro Wirasejati. PT. Adiputro Wirasejati memiliki banyak varian bus karoseri yang di produksi termasuk Jetbus 2 HD. Jetbus 2 HD menggunakan engine dari pabrikan lain sesuai dengan permintaan. PT. Adiputro Wirasejati sendiri tidak memiliki data performa karakteristik traksi dari engine yang digunakan oleh Jetbus 2 HD. Beberapa hal diatas yang mendasari penulis untuk melakukan Analisa Karakteristik Traksi serta Redesign Rasio Transmisi pada bus Adiputro.

Penelitian mengenai analisa karakteristik kendaraan sebelumya pernah dilakukan oleh Nico Yudha Wardhana [2]. Analisa karakteristik traksi dari mobil Toyota Fortuner 4.0 V6 SR pada kondisi standar. Melakukan dyno test terhadap kendaraannya terlebih dahulu untuk mengetahui torsi, power dan efisiensi dari transmisi mobil Toyota Fortuner 4.0 V6 SR. Melakukan perhitungan pada masing-masing tingkat kecepatan, mulai tingkat gigi 1 sampai ke 5 pada range putaran mesin 1600 sampai $5200 \mathrm{rpm}$. Hasil analisa yang dilakukan diperoleh beberapa informasi mengenai kinerja yang mampu dihasilkan oleh kendaraan, seperti traksi yang dihasilkan kendaraan, kecepatan maksimum yang mampu ditempuh, tanjakan maksimum yang mampu dilalui, serta percepatan yang mampu dihasilkan pada masing-masing gigi. Pada tingkat gigi pertama besarnya traksi maksimum untuk tingkat gigi pertama sebesar $8.80475 \mathrm{Nm}$ pada $3800 \mathrm{rpm}$ sehingga mobil ini mampu melewati jalanan dengan gradeability sebesar $50 \%$. Untuk tingkat gigi kedua, nilai traksi maksimum nya sebesar $5.107 \mathrm{kN}$, pada tingkat gigi ketiga sebesar $3.5019 \mathrm{kN}$, pada tingkat gigi keempat sebesar $2.5013 \mathrm{kN}$ dan pada tingkat gigi kelima sebesar $1.791 \mathrm{kN}$. Selain permasalahan losses traksi, tingkatan gigi ke 5 seolaholah tidak berfungsi saat digunakan akibat nilai traksi yang dihasilkan tidak mampu memenuhi kebutuhan gaya hambat kendaraan pada saat kecepatan tinggi. Oleh karena dilakukan redesain menjadi 7 tingkat keceptan.

Hasil dari redesaign dari mobil Toyota Fortuner 4.0 V6 SR dengan menggunakan 7 tingkat kecepatan. Menunjukan nilai traksi pada tingkat gigi terakhir lebih tinggi jika dibandingkan kondisi standar. Selain itu, losses traksi antara tingkat gigi pertama menuju tingkat gigi kedua memiliki losses traksi yang sedikit dari pada menggunakan 5 tingkat 
kecepatan, begitu. Sehingga, losses traksi untuk perpindahan gigi pertama menuju tingkat gigi kedua yang awalnya pada kondisi standar sebesar $4.564 \mathrm{kN}$ dapat diminimalisir sampai dengan $1 \mathrm{kN}$ setelah dilakukan redesign dengan 7 tingkat kecepatan.

\section{URAIAN PENELITIAN}

\section{A. Menghitung Gaya Hambat Kendaraan}

Analisa dimulai dengan memperhitungkan gaya hambat yang terjadi pada kendaraan yang ditunjukan pada gambar 1 . Gaya hambat yang diperhitungkan adalah gaya hambat rolling, gaya hambat angin, gaya hambat tanjakan. Sehingga dari ketiga gaya hambat tersebut didapat gaya hambat total berdasarkan variasi tanjakan. Untuk menghitung gaya hambat rolling menggunakan persamaan :

$$
\begin{aligned}
& R_{r}=f_{r} W \\
& f_{r}=f_{o}+f_{s}\left(\frac{V}{100}\right)^{2,5}
\end{aligned}
$$

dimana, $f_{o}$ dan $f_{s}$ adalah koefisien yang bergantung pada tekanan ban kendaraan dan $W$ adalah berat kendaraan. untuk menghitung gaya hambat angin menggunakan persamaan :

$$
R_{a}=\frac{1}{2} \times C_{d} \times A_{f} \times V_{a}^{2}
$$

dimana $\rho=$ massa jenis udara, $C_{d}=$ koefisien drag, $A f=$ luas frontal kendaraan, $V a=$ kecepatan relative angin. Sedangkan untuk gaya hambat tanjakan mengunakan persamaan :

$R_{g}=W \sin \theta$

dimana $\theta$ adalah sudut tanjakan. Selanjutnya dihitung gaya hambat total pada kendaraan menggunakan persamaan :

$F_{z}=R_{r}+R_{a}+R_{g}$

$$
F_{z}=f_{r} . W \cos \theta_{\max }+\frac{1}{2} \rho C_{d} A f V a^{2}+W \sin \theta_{\max }
$$

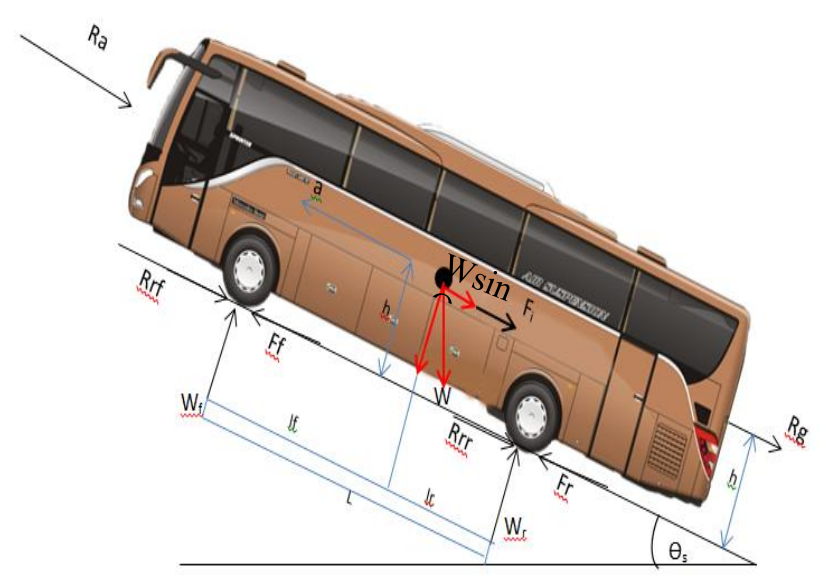

Gambar 1. Diagram Bodi Bebas Kendaraan Saat Menanjak

\section{B. Menghitung Gaya Dorong Kendaraan}

Gaya Dorong adalah gaya yang bekerja berlawanan dengan arah gerak gaya hambat kendaraan. Gaya dorong ini dihasilkan dari daya yang dihasilkan oleh mesin kendaraan (engine) yang kemudian disalurkan melalui sistem transmisi sehingga akhirnya dapat menggerakan roda. Untuk menghitung besarnya gaya dorong yang mampu dihasilkan kendaraan, dapat digunakan persamaan 7 .

$$
F_{t}=\frac{I_{t} \cdot I_{g} \cdot M_{e}}{r} \eta_{t}
$$

dengan $M_{e}$ adalah torsi engine, $I_{t}$ adalah rasio transmisi, $I_{g}$ adalah rasio gardan, $\eta_{t}$ adalah efisiensi transmisi

\section{Desain Tingkatan Gigi (Progressi Geometris)}

Salah satu cara untuk mencari perbandingan gigi antara tingkat transmisi terendah dan tertinggi adalah dengan cara progresi geometris. Cara ini umumnya dipakai sebagai langkah iterasi awal. Batas kecepatan operasi dari mesin terendah $\left(\mathrm{ne}_{1}\right)$ dan tertinggi $\left(\mathrm{ne}_{2}\right)$ harus ditetapkan terlebih dahulu. Penetapan ini berdasarkan karakteristik torsi dari mesin [3]

Langkah pertama untuk mendesain tingkat transmisi, harus ditentukan terlebih dahulu rasio transmisi pertama dan rasio transmisi terakhir kendaraan. Untuk menentukan rasio transmisi pertama $\left(i_{1}\right)$, dapat dihitung dengan rumus:

$$
\begin{aligned}
& i_{1}=\frac{F_{1} \cdot r}{M_{e} \cdot I_{g} \cdot \eta_{t}} \\
& F_{1}=\frac{W}{g} a+R_{a}+R_{r}(9)
\end{aligned}
$$

dengan $F_{1}$ adalah gaya maksimum saat tingkat gigi pertama, $M_{e}$ adalah torsi engine, $I_{t}$ adalah rasio transmisi, $I_{g}$ adalah rasio gardan, $\eta_{t}$ adalah efisiensi transmisi, $a$ adalah percepatan pada tingkat gigi pertama, $R_{a}$ adalah gaya hambat angin, $R_{r}$ adalah gaya hambat rolling.

Kemudian, rasio transmisi pada tingkat terakhir $\left(i_{n}\right)$ dirumuskan sebagai berikut :

$$
\begin{gathered}
i_{n}=\frac{F_{n} \cdot r}{M_{e} \cdot I_{g} \cdot \eta_{t}} \\
F_{n}=R_{r}+R_{a}
\end{gathered}
$$

dengan $F_{n}$ adalah gaya maksimum saat tingkat gigi terakhir, nilai faktor $K_{g}$ dapat ditentukan dengan rumus 10 . Selanjutnya, nilai $K_{g}$ tersebut digunakan untuk menentukan nilai $i_{2}, i_{3}$ dst.

$$
K_{g}=\left(\frac{i_{n}}{i_{1}}\right)^{\frac{1}{n-1}}
$$

dengan $K_{g}$ adalah rasio antar tingkat gigi 1 ke tingkat gigi berikutnya, $n$ adalah banyaknya tingkat gigi pada transmisi yang di desain. 


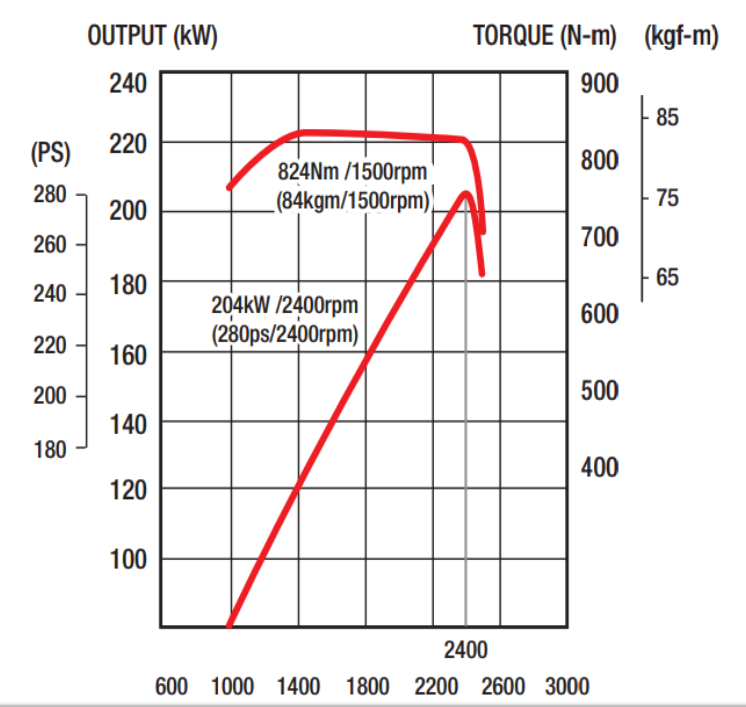

Gambar 2 Grafik Performa Jetbus 2 HD Engine J08E VD [4]

\section{J 08 E U N}

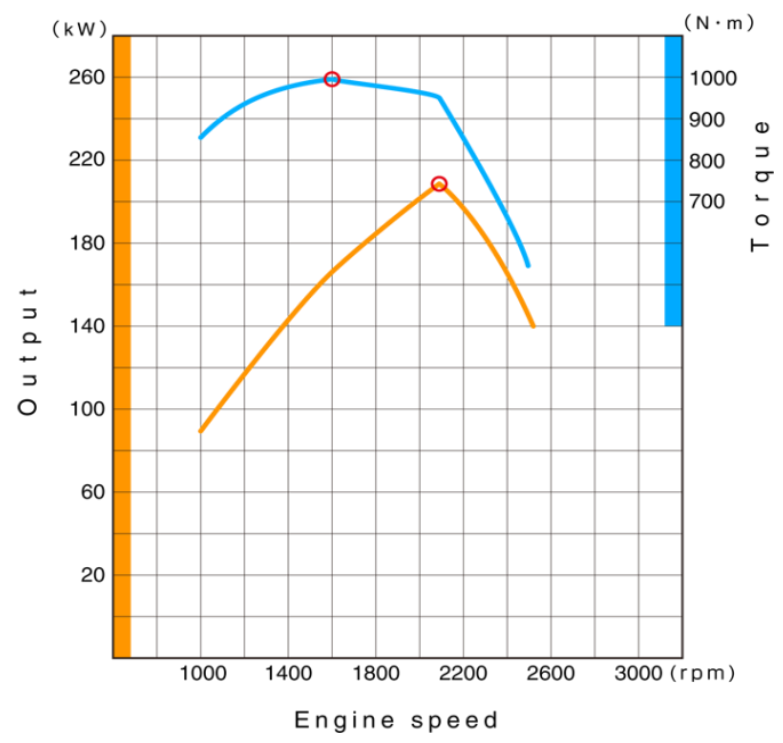

Gambar 3 Grafik Performa Jetbus 2 HD Engine J08E UN [5].

Pada Gambar 2 dan 3 merupakan peforma dari engine yang dianalisa. Gambar 1 adalah peforma dari engine J08E VD. Sedangkan untuk gambar 2 adalah peforma dari engine J08E UN. Kedua engine ini yang sering digunakan untuk Jetbus 2 HD Adiputro.

\section{HASIL DAN ANALISIS}

Berdasarkan data teknis dan spesifikasi kendaraan Jetbus 2 HD Adiputro, untuk membuat karakteristik traksi dan kinerja transmisinya dengan memperhatikan dalam beberapa batasan:

1. Analisa yang dilakukan dalam kondisi bus terisi penuh dengan berat $60 \mathrm{~kg} / \mathrm{orang}$

2. Tekanan ban $60 \mathrm{psi}$

3. Kinerja engine tidak dipengaruhi lingkungan sekitar
4. Menggunakan bahan bakar solar

5. Jalan yang dilalui rata (tidak bergelombang)

6. Beban angin yang terjadi pada kendaraan yaitu gaya hambat (drag)

Berikut ini hasil urutan perhitungan dan analisa data yang telah dilakukan,

\section{A. Hasil Perhitungan Gaya Hambat Kendaraan}

Dengan menggunakan rumus 6, maka di dapatkan grafik gaya hambat total pada gambar 4 .

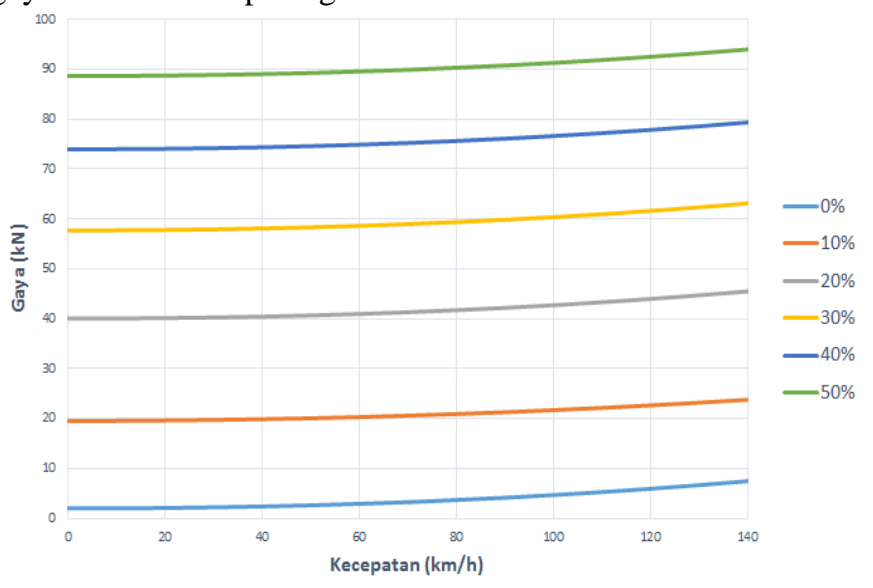

Gambar 4. Grafik Gaya Hambat Total Tanjakan Kendaraan.

\section{B. Hasil Perhitungan Gaya Dorong Kendaraan}

Nilai gaya dorong diperoleh menggunakan rumus 5 . Dalam melakukan perhitungan gaya dorong rasio gigi $\left(I_{t}\right)$, rasio garden $\left(I_{g}\right)$, torsi mesin $\left(M_{e}\right)$ dan jari-jari roda $(r)$ menggunakan spesifikasi dari data engine $\mathrm{Hino}^{[3]}$. Efisiensi transmisi $\left(\eta_{t}\right)$ diperoleh dari perhitungan efisiensi di tiap komponen transmisi, yaitu bantalan dan gear. Pada setiap tingkat kecepatan daya yang di salurkan oleh transmisi melewati 2 pasang gear dan 4 bantalan. Dimana setiap pasang gear memiliki efisiensi $96 \%$ sedangkan setiap bantalan memiliki efisiensi $99 \%$. Efisiensi total yang di dapat diperoleh dengan perkalian antar komponen tersebut dan menghasilkan efisiensi total sebesar $87 \%$.

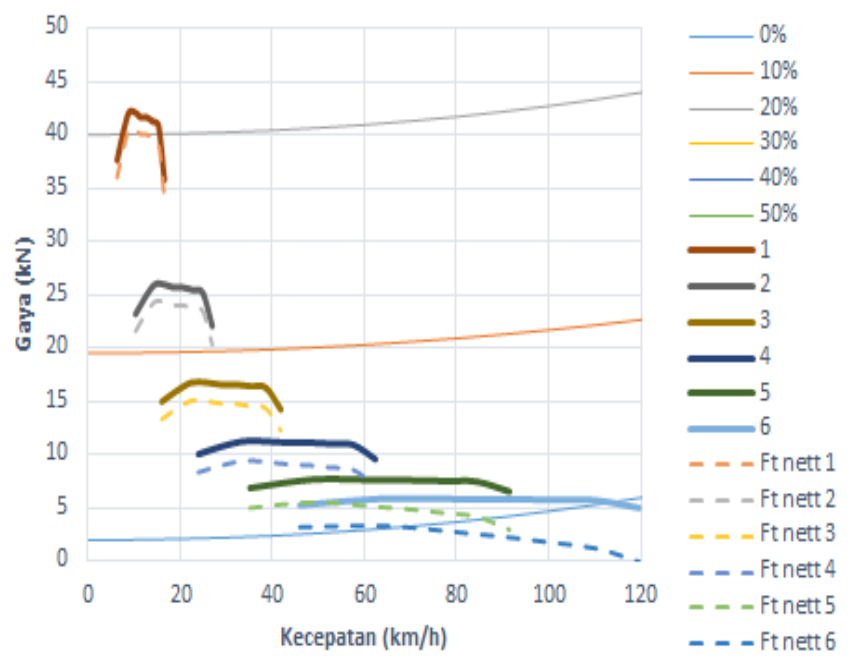

Gambar 5. Grafik Karakteristik Traksi Engine J08E VD Standar 


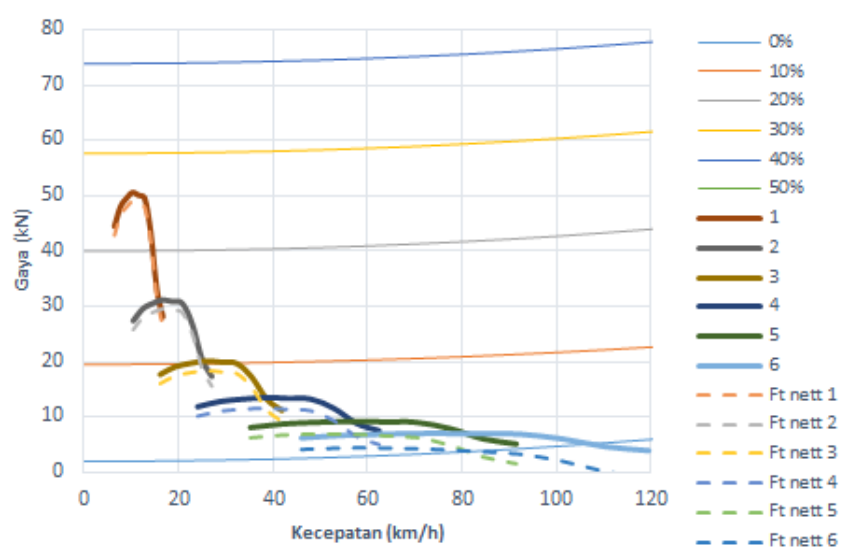

Gambar 6. Grafik Karakteristik Traksi Engine J08E UN Standar

Gambar 5 merupakan grafik karakteristik untuk engine J08E VD sedangkan gambar 6 merupakan grafik karakteristik traksi engine J08E UN. Hasil kedua karakteristik traksi tersebut masih belum sesuai dengan klam pabrikan yaitu mampu menempuh gradeability $32.3 \%$. Kecepatan maksimum yang mampu dicapai dari Jetbus 2 HD dengan engine J08E VD sebesar $116 \mathrm{Km} / \mathrm{jam}$ untuk kecepatan maksimum Jetbus $2 \mathrm{HD}$ dengan engine J08E UN sebesar $117 \mathrm{Km} / \mathrm{jam}$.

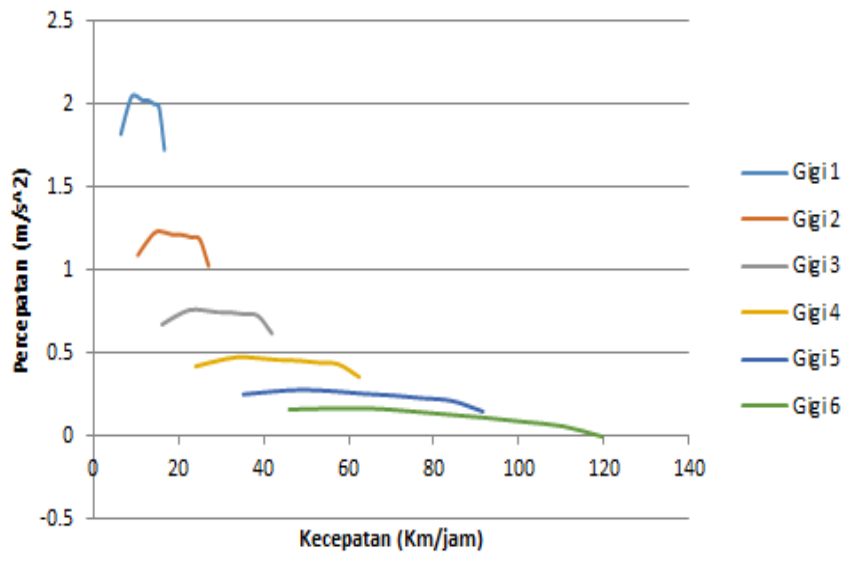

Gambar 7. Grafik Percepatan Engine J08E VD Standar

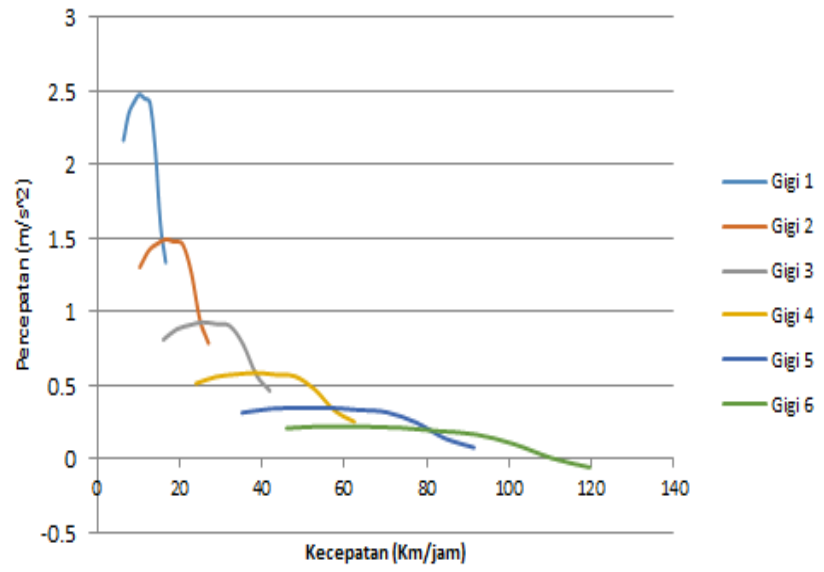

Gambar 8. Grafik Percepatan Engine J08E UN Standar
Pada gambar 7 dan gambar 8 menunjukan hasil percepatan yang mampu dicapai oleh Jetbus 2 HD dengan engine J08E VD dan engine J08E UN. Percepatan maksimal untuk Jetbus 2 HD dengan engine J08E VD sebesar 2.0471 $\mathrm{m} / \mathrm{s}^{2}$ pada tingkat gigi pertama. Untuk percepatan maksimal Jetbus 2 HD dengan engine J08E UN sebesar $2.4755 \mathrm{~m} / \mathrm{s}^{2}$ pada tingkat gigi pertama.

\section{Hasil Perhitungan Redesign Rasio Transmisi}

Tingkat gigi pertama dirancang dengan mengunakan rumus 8. Dalam melakukan perhitungan redesign rasio transmisi terlebih dulu menghitung percepatan maksimal yang diingkan untuk tingkat gigi awal. Dengan memisalkan kecepatan maksimum yang ingin dicapai bus pada tingkat gigi pertama adalah $10 \mathrm{~km} / \mathrm{jam}$, asumsi saat bus melaju pada tingkat gigi pertama gaya hambat yang dialami hanya gaya hambat rolling di tambah dengan percepatan yang ingin dicapai. Daya maksimum engine J08E VD sebesar $204 \mathrm{~kW}$ dan daya maksimum engine J08E UN sebesar $210 \mathrm{~kW}$. Gaya hambat kendaraan, nilai $\mathrm{Rr}$ pada saat kecepatan $10 \mathrm{~km} / \mathrm{jam}$ sebesar 1584.93 newton

$$
P \max =R r \cdot V+\frac{W}{g} \cdot a \cdot V(13)
$$

Hasil percepatan dari perhitungan untuk engine J08E VD adalah $3.4341 \mathrm{~m} / \mathrm{s}^{2}$ dan untuk engine J08E UN adalah 3.5351 $\mathrm{m} / \mathrm{s}^{2}$. Setelah percepatan maksimum didapat selanjutnya perhitungan dilakukan untuk mencari $F_{1}$ dengan rumus 9 .

Hasil gaya dorong tingkat kecepatan pertama dari perhitungan untuk engine J08E VD adalah $69606.39 \mathrm{~N}$ dan untuk engine J08E UN adalah 71601.7 N. Dilajutkan menghitung rasio tingkat gigi pertama dengan menggunakan rumus 8. Didapatkan rasio gigi pertama untuk engine J08E VD adalah 11.8547 dan untuk engine J08E UN adalah 10.1498 .

Menghitung tingkat gigi terakhir menggunakan rumus 9 . Rasio tingkat gigi terakhir ini berdasarkan kecepatan maksimum yang ingin di capai oleh kendaraan, yaitu 120 $\mathrm{km} / \mathrm{jam}$. Saat berada pada tingkat gigi terakhir, beban yang dialami adalah gaya hambat rolling dan gaya hambat angin. Sehingga $F_{n}$ dapat dihitung menggunakan rumus 11 .

Hasil gaya dorong tingkat kecepatan terakhir dari perhitungan untuk engine J08E VD dan engine J08E UN adalah $5072 \mathrm{~N}$. Dilajutkan menghitung rasio tingkat gigi terakhir dengan menggunakan rumus 9. Didapatkan rasio gigi terakhir untuk engine J08E VD adalah 0.86382 dan untuk engine J08E UN adalah 0.718978 .

Hasil perhitungan redesign rasio transmisi engine $\mathrm{J} 08 \mathrm{E}$ VD dapat dilihat pada tabel 1 . Sedangkan hasil perhitungan redesign rasio transmisi engine J08E UN dapat dilihat pada tabel 2. Engine J08E VD melakukan hingga redesign 8 tingkat kecepatan karena pada redesign 6 dan 7 tingkat kecepatan terjadi losses energy yang besar. Walaupun pada 8 tingkat kecepatan juga terjadi losses energy namun tidak dilanjutkan untuk penambahan tingkat kecepatan lagi karena akan membuat pengemudi susah mengendarai bus. Sedangkan untuk engine J08E UN hanya melakukan redesign 6 tingkat kecepatan. 
Tabel 1.

Hasil Perhitungan $\mathrm{K}_{\mathrm{g}}$ dan Rasio Tingkat Transmisi Engine J08E VD

\begin{tabular}{ccccc} 
Tingkat & Standart & 6 & 7 & 8 \\
\hline Kg & 0.573 & 0.5922 & 0.6462 & 0.6878 \\
Rasio 1 & 7.716 & 11.8547 & 11.8547 & 11.8547 \\
Rasio 2 & 4.423 & 7.021 & 7.6615 & 8.1545 \\
Rasio 3 & 2.854 & 4.1582 & 4.9515 & 5.6092 \\
Rasio 4 & 1.915 & 2.4627 & 3.2 & 3.8583 \\
Rasio 5 & 1.301 & 1.4585 & 2.0681 & 2.654 \\
Rasio 6 & 1 & 0.86382 & 1.3366 & 1.8256 \\
Rasio 7 & & & 0.86382 & 1.2557 \\
Rasio 8 & & & & 0.86382 \\
\hline \hline
\end{tabular}

Tabel 2.

Hasil Perhitungan $\mathrm{K}_{\mathrm{g}}$ Dan Rasio Tingkat Transmisi Engine J08E UN

\begin{tabular}{ccc}
\hline \hline Tingkat & Standart & 6 \\
\hline Kg & 0.573 & 0.5889 \\
Rasio 1 & 7.716 & 10.1498 \\
Rasio 2 & 4.423 & 5.97738 \\
Rasio 3 & 2.854 & 3.52015 \\
Rasio 4 & 1.915 & 2.07306 \\
Rasio 5 & 1.301 & 1.22085 \\
Rasio 6 & 1 & 0.718978 \\
\hline \hline
\end{tabular}

Hasil karakteristik traksi redesign engine J08E VD dengan 6, 7 dan 8 tingkat kecepatan dapat dilihat pada gambar 9, 10 dan 11. Dari hasil redesign kecepatan engine J08E VD mampu mencapai kecepatan $120 \mathrm{~km} / \mathrm{jam}$ dan gradeability mampu mencapai $37 \%$. Hasil karakteristik traksi redesign engine J08E UN dengan 6 tingkat kecepatan dapat dilihat pada gambar 12. Dari hasil redesign kecepatan engine J08E UN mampu mencapai kecepatan $120 \mathrm{~km} / \mathrm{jam}$ dan gradeability mampu mencapai $39 \%$.

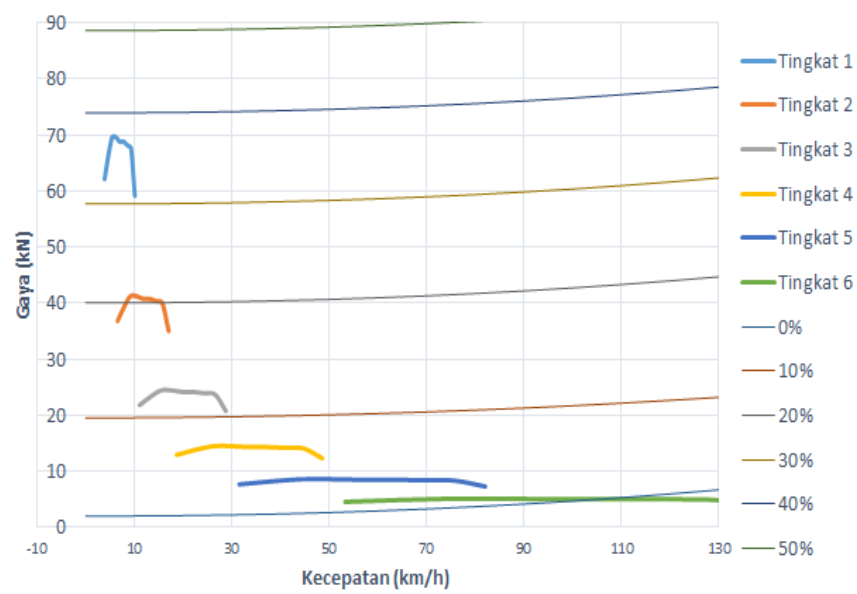

Gambar 9. Grafik Karakteristik Traksi Engine J08E VD 6 Tingkat Kecepatan Hasil Redesign

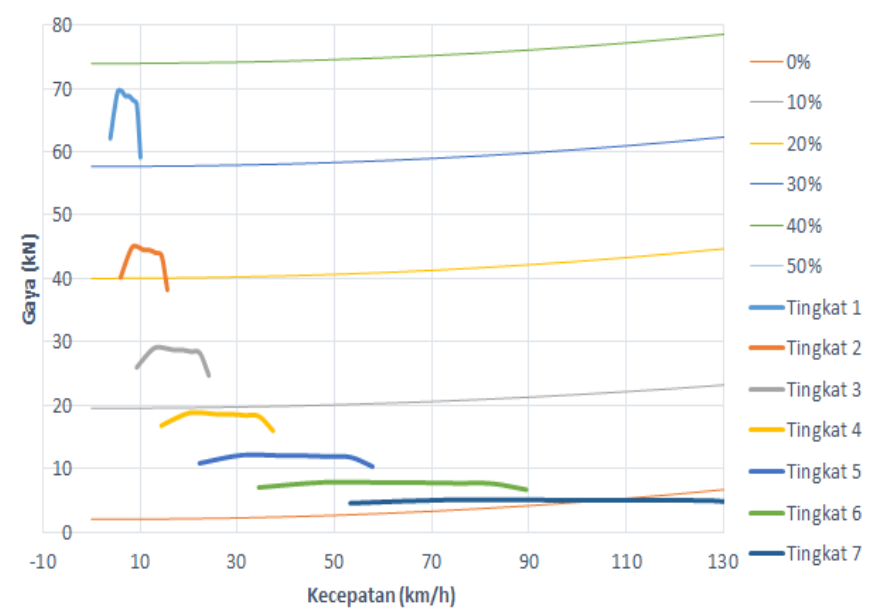

Gambar 10. Grafik Karakteristik Traksi Engine J08E VD 7 Tingkat Kecepatan Hasil Redesign

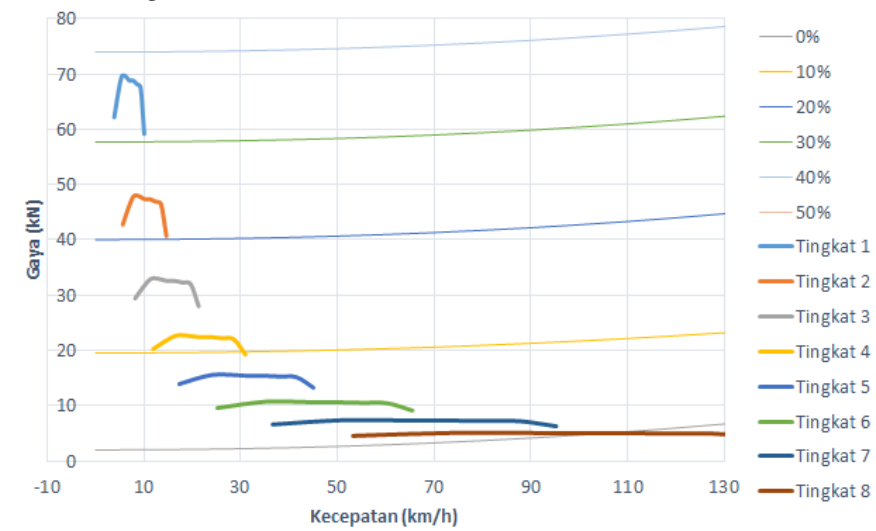

Gambar 11. Grafik Karakteristik Traksi Engine J08E VD 8 Tingkat Kecepatan Hasil Redesign

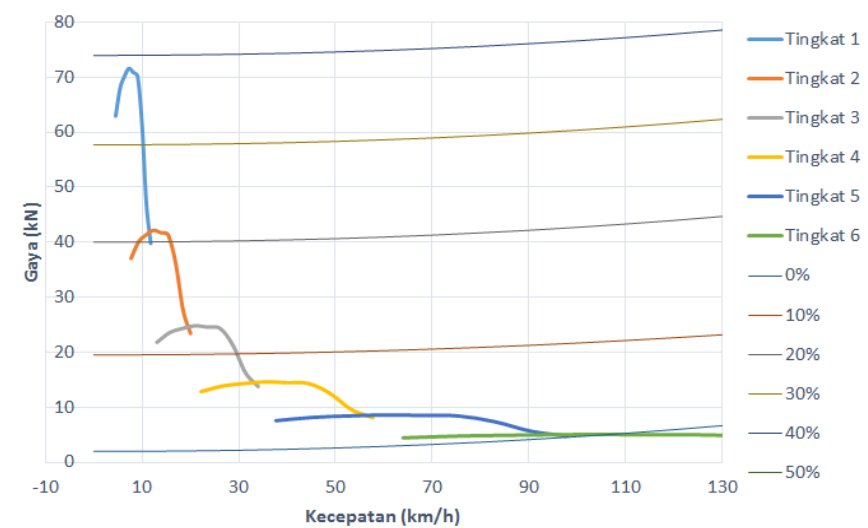

Gambar 12. Grafik Karakteristik Traksi Engine J08E UN 6 Tingkat Kecepatan Hasil Redesign

Tabel 3.

Pemilihan Rasio Transmisi Dan Engine Berdasarkan Faktor Tertentu

\begin{tabular}{|c|c|c|c|c|c|}
\hline \multirow[b]{2}{*}{ Faktor } & \multirow[b]{2}{*}{ Bobot } & \multicolumn{3}{|c|}{ Redesain Engine J08E VD } & \multirow{2}{*}{$\begin{array}{l}\text { Redesain Engine } \\
\text { J08E UN } 6 \\
\text { Kecepatan }\end{array}$} \\
\hline & & 6 & 7 & 8 & \\
\hline Efisiensi & 0.4 & 3 & 2 & 1 & 3 \\
\hline Konstruksi & & & & & \\
\hline Losse energy & 0.1 & 1 & 1 & 1 & 3 \\
\hline Efisiensi Transmis & 0.2 & 3 & 2 & 1 & 3 \\
\hline Kecepatan & 0.15 & 2 & 2 & 2 & 3 \\
\hline Gradeability & 0.15 & 2 & 2 & 2 & 3 \\
\hline Jumlah & 1 & 11 & 9 & 7 & 15 \\
\hline
\end{tabular}




\section{KESIMPULAN}

Berdasarkan data dan analisa yang telah dilakukan, diperoleh beberapa kesimpulan penelitian sebagai berikut,

1. Pada kondisi standar, kendaraan Jetbus 2 High Deck Adiputro dengan engine Hino J08E VD mampu menempuh kecepatan maksimum sebesar $116 \mathrm{~km} / \mathrm{jam}$ pada tingkat gigi ke-enam dan mampu melaju pada jalan dengan gradeability maksimum $22 \%$ serta percepatan maksimum sebesar $2.0471 \mathrm{~m} / \mathrm{s}^{2}$ pada tingkat kecepatan pertama. Sedangkan dengan engine Hino J08E UN mampu menempuh kecepatan maksimum sebesar 117 $\mathrm{km} / \mathrm{jam}$ pada tingkat gigi ke-enam dan mampu melaju pada jalan dengan gradeability maksimum $25 \%$ serta percepatan maksimum sebesar $2.4755 \mathrm{~m} / \mathrm{s}^{2}$ pada tingkat kecepatan pertama.. Dari hasil 2 engine tersebut dapat dikatakan bahwa karakteristik traksi kendaran tidak sesuai dengan klaim pabrikan yang dicantumkan pada brosur kendaraan.

2. Setelah dilakukan redesign pada 6,7 , maupun 8 tingkat kecepatan untuk engine Hino J08E VD , traksi yang dihasilkan oleh kendaraan meningkat dari $42.134 \mathrm{kN}$ menjadi $69.6064 \mathrm{kN}$ pada tingkat gigi pertama pada putaran $1600 \mathrm{rpm}$. Peningkatan gaya dorong tersebut mengakibatkan kemampuan kendaraan untuk melalui jalan tanjak dengan gradeability sebesar $37 \%$ dari kondisi standart $22 \%$. Kecepatan maksimum yang dapat di capai meningkat dari $117 \mathrm{~km} / \mathrm{jam}$ menjadi sebesar $120 \mathrm{~km} / \mathrm{jam}$.

3. Setelah dilakukan redesign pada 6 tingkat kecepatan untuk engine Hino J08E UN , traksi yang dihasilkan oleh kendaraan meningkat dari $50.1114 \mathrm{kN}$ menjadi 71.6017 $\mathrm{kN}$ pada tingkat gigi pertama pada putaran $1600 \mathrm{rpm}$. Peningkatan gaya dorong tersebut mengakibatkan kendaraan mampu melalui jalan tanjak dengan gradeability sebesar 39\%. Sedangkan kecepatan maksimum yang dapat di capai meningkat dari 117 $\mathrm{km} / \mathrm{jam}$ menjadi sebesar $120 \mathrm{~km} / \mathrm{jam}$.

4. Engine yang tepat untuk Jetbus 2 High Deck Adiputro dari hasil analisa traksi dan redesign ratio transmisi adalah engine Hino J08E UN dengan jumlah tingkatan yang digunakan adalah 6 tingkat dengan redesign rasio transmisi dengan rasio tiap transmisinya 10.1498; 5.9773; 3.52015 ; 2.07306; 1.22085; 0.718978, karena memiliki gaya dorong yang mampu menanjak dengan gradeability $39 \%$. Redesign dengan 6 tingkat kecepatan memiliki efisiensi konstruksi yang paling besar sehingga cukup jika menggunakan transmission case standar karena perubahan yang signifikan hanya ada pada perubahan dimensi pasangan gear pertama. Selain itu losses energy yang terjadi pada 6 tingkat kecepatan ini sudah tidak ada sehingga tidak diperlukan penambahan jumlah tingkat kecepatan.

\section{DAFTAR PUSTAKA}

[1] Gaikindo, "Pasar Domestik Fluktuatif, Penjualan Doubel Cabin Melesat," 2017. [Online]. Available: https://www.gaikindo.or.id/data-gaikindo-pasar-domestik-fluktuatifpenjualan-double-cabin-melesat/.

[2] N. Wardhana, "Analisis Karakteristik Traksi Serta Redesign Rasio Transmisi Toyota Fortuner 4.0 V6 SR (AT 4 x 4)," Surabaya, 2016.

[3] dan B. S. Sutantra, I Nyoman, Teknologi Otomotif, Edisi Kedua. Surabaya: Guna Widya, 2010.

[4] Hino, "RK8JBus," 2015. .

[5] Hino, "J08Series," $2015 . \quad$ [Online]. Available: http://www.hinoglobal.com/products/dieselengines/Engine_J08.htm 